ISSN 1392-3196 / e-ISSN 2335-8947

Zemdirbyste-Agriculture, vol. 100, No. 3 (2013), p. 289-292

DOI 10.13080/z-a.2013.100.037

\title{
Diversity and sex ratio of thrips (Thysanoptera) species in winter wheat in Lithuania
}

\author{
Remigijus ŠMATAS, Kęstutis TAMOŠIŪNAS, Vida DANYTE் \\ Institute of Agriculture, Lithuanian Research Centre for Agriculture and Forestry \\ Instituto 1, Akademija, Kèdainiai distr., Lithuania \\ E-mail: remigijus@lzi.lt
}

\begin{abstract}
A study on the variation of species diversity and sex ratio of thrips in winter wheat (Triticum aestivum L.) was conducted at the Lithuanian Institute of Agriculture (currently - Lithuanian Research Centre for Agriculture and Forestry). Assessments of thrips abundance were carried out from the beginning of tillering (growth stage (GS) 21) until complete maturity (GS 89). Thirteen thrips species belonging to the three families were identified: 10 thrips species belonged to Thripidae, 2 to Phlaeothripidae and 1 to Aeolothripidae families. In terms of the feeding group, one species (Aeolothrips intermedius) belonged to zoophagous, the rest of the species were phytophagous. Frankliniella intonsa, F. tenuicornis, Haplothrips aculeatus and Limothrips denticornis were the earliest thrips species identified on winter wheat in spring. The dominating species were L. denticornis (41.3\%), H. aculeatus $(25.8 \%)$ and F. tenuicornis $(20.5 \%)$. An average sex ratio of $L$. denticornis was $84.7 \%$, and of $H$. aculeatus $68.2 \%$, and of $F$. tenuicornis $-71.1 \%$ and of $F$. intonsa $-60.9 \%$.
\end{abstract}

Key words: cereal thrips, Frankliniella tenuicornis, Haplothrips aculeatus, Limothrips denticornis, Triticum aestivum.

\section{Introduction}

Wheat (Triticum aestivum L.) is a worldwide cultivated cereal crop. Globally, wheat production exceeds that of all other cereal crops (Varshney et al., 2006). In Lithuania, winter wheat also is one of major crops and their importance has been increasing over the past years. If in 2008 the area under winter wheat was 290 thousand hectares, by 2009 it had increased to 397.2 thousand hectares. Many pest species can damage winter wheat and none of winter wheat variety has been found to be fully immune to any of the species (Gaafar et al., 2011) Thrips are very important in the ecosystem. Most of the lately described species are herbivorous and thrips are among the major pests of wheat. On the global scale thrips fauna can cause serious damage to winter wheat (Schröder, 2009), and current methods of control are not fully sufficient to prevent crop damage. About 90 thrips species are economically important. Nine of them (in the genus Tospovirus) are plant viruse vectors (Ullman et al., 1997). The dominating species of thrips in winter cereals are more or less the same; however, the data of different authors about the species composition are diverse. According to Zawirska and Wałkowski (2000), Limothrips denticornis is a very common and abundant species in Poland. Kąkol and Kucharczyk (2004) have reported that L. denticornis and Haplothrips aculeatus are most common among the five thrips species in winter and spring wheat. Larsson $(1988 ; 2005)$ have reported that in Sweden common species in rye are L. denticornis, L. cerealium, H. aculeatus, Thrips angusticeps and Frankliniella tenuicornis. In Finland, in winter rye and other cereals $L$. denticornis, $H$. aculeatus, $F$. tenuicornis and Anaphothrips obscurus were found (Köppä, 1970). A survey of thrips (Thysanoptera) in cereals was carried out in south eastern Norway in 1996. No high densities of thrips were recorded. L. denticornis and F. tenuicornis were the dominating species. Stenothrips graminum, which is new to the Norwegian fauna, was also found in abundance. L. denticornis reproduced in cereals only to a small extent. F. tenuicornis completed two generations, one in winter cereals in June, and a second generation in spring cereals in July (Kobro et al., 2000). Thrips species, $H$. tritici, $H$. aculeatus, L. denticornis, L. cerealium, F. tenuicornis and T. angusticeps were recorded on different wheat varieties (Andjus, 1998). Some authors noted that the number of thrips on cereals is increasing (Kąkol, Kucharczyk, 2004). Different thrips species can attack crops in different parts of the world. In Europe, this is very characteristic of cereal thrips (Kobro et al., 2000). In Lithuania thrips are one of the main insect pests in cereal crops (Šmatas, 2007). Thrips occurrence in winter wheat is more than eight-fold lower compared with winter rye (Šmatas, Šurkus, 2005).

Very important in the knowledge of the biotic potential is the sex ratio index of the population. Most species are bisexual, but females are often dominant in field populations (Vasiliu-Oromulu, 2001). In some species, reproduction is partly or wholly parthenogenetic and males are rare or unknown. Sex ratio can be influenced by year, host plant, the latitude (Köppä, 1970; VasiliuOromulu, 2001).

The aim of our investigation was to determine Thysanoptera species biodiversity in winter wheat. 


\section{Materials and methods}

Investigations were carried out at the Lithuanian Institute of Agriculture (currently - Lithuanian Research Centre for Agriculture and Forestry), Department of Plant Pathology and Protection. Investigations on the variation of species diversity and abundance of thrips were carried out in winter wheat according to the same methods as in rye (Šmatas, 2009).

\section{Results and discussion}

A total of 1382 adult thrips and 1009 of their larvae were collected and 13 thrips species were indentified in the observation sites. The observed thrips species belonged to three families: Aeolothripidae family - Aeolothrips intermedius (Bagnall, 1934), Thripidae family - Anaphothrips obscurus (Müler, 1776), Aptinothrips rufus (Haliday, 1836), Aptinothrips stylifer (Trybom, 1894), Chirothrips manicatus (Haliday, 1836), Frankliniella intonsa (Trybom, 1895), Frankliniella pallida (Uzel, 1895), Frankliniella tenuicornis (Uzel, 1895), Limothrips denticornis (Haliday, 1836), Thrips angusticeps (Uzel, 1895), Thrips tabaci (Lindeman, 1888), Phlaeothripidae family - Haplothrips aculeatus (Fabricius, 1803), Haplothrips leucanthemi (Schrank, 1781) (Tables 1-2). All species found belonged to phytophagous trophic status and only one species (A. intermedius) belonged to zoophagous trophic status.

Table 1. Species diversity of adult thrips in winter wheat

\begin{tabular}{|c|c|c|c|c|c|c|}
\hline \multirow{3}{*}{ Thrips species } & \multicolumn{6}{|c|}{ Total number of thrips found } \\
\hline & \multicolumn{3}{|c|}{ Females } & \multicolumn{3}{|c|}{ Males } \\
\hline & number & spread period & GS & number & spread period & GS \\
\hline \multicolumn{7}{|c|}{2002} \\
\hline Anaphothrips obscurus & 27 & May III-July I & $43-83$ & 0 & - & - \\
\hline Chirothrips manicatus & 6 & May I, June I-II & $32,69-73$ & 0 & - & - \\
\hline Frankliniella intonsa & 17 & $\begin{array}{l}\text { April III, } \\
\text { May II-July I }\end{array}$ & $\begin{array}{l}29-30 \\
33-77\end{array}$ & 7 & May III-June III & $43-75$ \\
\hline F.pallida & 2 & May III, June II & 59,71 & 0 & - & - \\
\hline F. tenuicornis & 77 & April III-July II & $29-92$ & 29 & May III-July I & $47-77$ \\
\hline Haplothrips aculeatus & 192 & April III-July II & $29-92$ & 61 & April III-July II & $29-92$ \\
\hline H. leucanthemi & 1 & June II & 71 & 0 & - & - \\
\hline Limothrips denticornis & 256 & May I-July II & 30-92 & 39 & June I-July I & $69-83$ \\
\hline Thrips tabaci & 5 & June I,June III & $65-69,75$ & 0 & - & - \\
\hline Total & 583 & & & 136 & & \\
\hline \multicolumn{7}{|c|}{2003} \\
\hline Aeolothrips intermedius & 1 & July II & 75 & 1 & July III & 83 \\
\hline Anaphothrips obscurus & 14 & June I, June III-July III & $51,69-87$ & 0 & - & - \\
\hline Aptinothrips rufus & 2 & July I & $73-75$ & 0 & - & - \\
\hline A. stylifer & 2 & July I & $73-75$ & 0 & - & - \\
\hline Chirothrips manicatus & 4 & July I-III & $73-83$ & 0 & - & - \\
\hline Frankliniella intonsa & 29 & $\begin{array}{c}\text { May II, } \\
\text { June I-July III }\end{array}$ & $\begin{array}{c}29 \\
45-85\end{array}$ & 28 & $\begin{array}{l}\text { June II-III, } \\
\text { July II-III }\end{array}$ & $\begin{array}{l}55-73 \\
75-85\end{array}$ \\
\hline F.pallida & 15 & June I-July III & $43-83$ & 0 & - & - \\
\hline F. tenuicornis & 123 & May II, June I-July III & $29,45-83$ & 54 & June II-July III & $55-83$ \\
\hline Haplothrips aculeatus & 65 & May II-August I & $30-89$ & 39 & $\begin{array}{l}\text { May III-June II, July I, } \\
\text { July III-August I }\end{array}$ & $\begin{array}{c}32-69,73 \\
77-89\end{array}$ \\
\hline Limothrips denticornis & 228 & May I-August I & 29-89 & 48 & June II-July II & 69-77 \\
\hline Thrips angusticeps & 2 & June III & 73 & 0 & - & - \\
\hline T. tabaci & 8 & June I-II, July II & $47-65,75-77$ & 0 & - & - \\
\hline Total & 493 & & & 170 & & \\
\hline
\end{tabular}

I, II, III - ten-day periods, GS - growth stage

The most numerous species each year was L. denticornis reaching as many as $41.0 \%$ of all specimens collected in 2002, and $41.6 \%$ in 2003. This species also was the most numerous $(79.3 \%)$ in winter rye in Lithuania (Šmatas, 2009). L. denticornis is the second numerous species in winter cereals in Poland and according to various authors constitute 19.3\% (Szeflińska, 2005) $27.6 \%$ (Zawirska, Wałkowski, 2000) of all individuals found in rye. In Yugoslavia L. denticornis is the main species on barley (Andjus, 1998). In North Europe and North America L. denticornis is one of main thrips species in rye (Mound, 1997), but other authors (Buntin, Beshear, 1995) did not find $L$. denticornis in rye in North America at all. According Polish sources in spring, the females of $L$. denticornis appear in the field very early (Zawirska, Walkowski, 2000). According our experiments it also seems true. They were the earliest species of thrips found on winter wheat in spring 2003 and in spring 2002 they appeared also early. First $L$. denticornis females in spring were found from the first decade of May in both experimental years.
$H$. aculeatus and $F$. tenuicornis appeared in winter wheat field ten days earlier in 2002 and at the same time as L. denticornis in 2003 and were the second dominating species (35.2-14.7\% in 2002 and $15.7-26.7 \%$ in 2003). Smatas (2009) has reported that H. aculeatus is the second and F. tenuicornis the third dominating species in winter rye. In Poland, H. aculeatus is the main species on rye and constitutes $65.2 \%$ (Zawirska, Wałkowski, 2000). This disagrees with the data of Szeflińska (2005) who has indicated that this species takes the third place and constitutes $12.2 \%$ of all thrips found on rye. In Finland, $H$. aculeatus takes the fourth place and it is often found on rye and winter wheat Köpä (1970). In North Europe, H. aculeatus is one of the six most important thrips on rye (Mound, 1997). It seems that particularly in Lithuania $F$. tenuicornis can be as numerous as $H$. aculeatus in winter wheat. Other authors (Kąkol, Kucharczyk, 2004; Szeflińska, 2005) also found $F$. tenuicornis and $H$. aculeatus on rye or other cereals. Zawirska and Wałkowski (2000) call F. tenuicornis "cereal" thrips. The abundance of this species in their 
investigations in rye was $0.8 \%$. A. obscurus constituted $2.1-3.8 \%, F$. intons $a-3.3-8.6 \%$ and other species - less than $2.5 \%$. Simpson's index is heavily weighted towards the most abundant species in the sample while being less sensitive to species richness (Magurran, 1988). The Simpson diversity index was sufficiently high 0.68 and 0.72 in 2002 and 2003, respectively. That means the diversity of thrips species in winter wheat was high.

Table 2. Species diversity of adult thrips and their total number in winter wheat

\begin{tabular}{|c|c|c|c|c|c|c|}
\hline \multirow{3}{*}{ Thrips species } & \multicolumn{6}{|c|}{ Total number of thrips found } \\
\hline & \multicolumn{2}{|c|}{2002} & \multicolumn{2}{|c|}{2003} & \multicolumn{2}{|c|}{$2002-2003$} \\
\hline & number & $\%$ & number & $\%$ & number & $\%$ \\
\hline Aeolothrips intermedius & 0 & 0 & 2 & 0.3 & 2 & 0.1 \\
\hline Anaphothrips obscurus & 27 & 3.8 & 14 & 2.1 & 41 & 3.0 \\
\hline Aptinothrips. rufus & 0 & 0 & 2 & 0.3 & 2 & 0.1 \\
\hline A. stylifer & 0 & 0 & 2 & 0.3 & 2 & 0.1 \\
\hline Chirothrips manicatus & 6 & 0.8 & 4 & 0.6 & 10 & 0.7 \\
\hline Frankliniella intonsa & 24 & 3.3 & 57 & 8.6 & 81 & 5.9 \\
\hline F.pallida & 2 & 0.3 & 15 & 2.3 & 17 & 1.2 \\
\hline F. tenuicornis & 106 & 14.7 & 177 & 26.7 & 283 & 20.5 \\
\hline Haplothrips aculeatus & 253 & 35.2 & 104 & 15.7 & 357 & 25.8 \\
\hline H. leucanthemi & 1 & 0.1 & 0 & 0 & 1 & 0.1 \\
\hline Limothrips denticornis & 295 & 41.0 & 276 & 41.6 & 571 & 41.3 \\
\hline Thrips angusticeps & 0 & 0 & 2 & 0.3 & 2 & 0.1 \\
\hline T. tabaci & 5 & 0.7 & 8 & 1.2 & 13 & 0.9 \\
\hline Total & 719 & & 663 & & 1382 & \\
\hline Simpson index & & & & & & \\
\hline \multicolumn{3}{|c|}{$\begin{array}{l}\text { The larvae of the thrips found also were } \\
\text { identified (Table 3). In the winter wheat, the prevalent } \\
\text { genus was Haplothrips spp. (accounted for } 64.4 \% \text { and } \\
37.4 \% \text { in } 2002 \text { and } 2003 \text {, respectively of the total content } \\
\text { of thrips larvae). Limothrips spp. larvae constituted on } \\
\text { average } 34.9 \text { and } 9.0 \text { in } 2002 \text { and } 2003 \text {, respectively. }\end{array}$} & \multicolumn{4}{|c|}{$\begin{array}{l}\text { More than half }(53.4 \%) \text { specimens in } 2003 \text { consisted of } \\
\text { all other species. The Limothrips spp. larvae were found } \\
\text { from flowering to fruit development stages each year. } \\
\text { The Haplothrips spp. larvae spread for a longer period } \\
\text { compared with Limothrips spp. larvae - to full ripening } \\
\text { stages. }\end{array}$} \\
\hline
\end{tabular}

Table 3. Genus diversity of thrips larvae and their total number in winter wheat

\begin{tabular}{|c|c|c|c|c|}
\hline \multirow{2}{*}{ Thrips genus } & \multicolumn{4}{|c|}{ Total number of thrips larvae found } \\
\hline & number & spread period & GS & $\%$ \\
\hline \multicolumn{5}{|c|}{2002} \\
\hline Haplothrips spp. & 356 & June I-July II & $65-92$ & 64.3 \\
\hline Limothrips spp. & 39 & June I-II & $65-73$ & 7.0 \\
\hline Other thrips larvae & 159 & May I-July I & $32-77$ & 28.7 \\
\hline Total & 554 & & & \\
\hline \multicolumn{5}{|c|}{2003} \\
\hline Haplothrips spp. & 170 & June II-August I & 69-89 & 37.4 \\
\hline Limothrips spp. & 42 & June II-July I & $61-75$ & 9.2 \\
\hline Other thrips larvae & 243 & May III, June II-July III & $37,55-85$ & 53.4 \\
\hline Total & 455 & & & \\
\hline
\end{tabular}

I, II, III - ten-day periods, GS - growth stage

Sex ratio of free-living phytopagous thrips such as those found on crops, herbacious plants, and flowers is low, despite the fact that these species are among more obvious and well studied representatives of the order (Wrensch, Ebbert, 1993). According to investigations carried out by Sęczkowska (1970), the percent of males hatched is a little higher than that of females, but the number of adult females is higher than males. The researcher indicates that high natural mortality rate of males after copulation is responsible for this. VasiliuOromulu (2001) explains this by the influence of the latitude. Köpä (1970) claims that sex ratio of $L$. denticornis can markedly differ between years. In our study, sex ratio of all collected thrips was $81.1 \%$ in 2002 and $74.4 \%$ in 2003. Šmatas (2009) determined that sex ratio of $L$. denticornis on rye in Lithuania was $59.9-64.5 \%$. Köpä (1970) found that sex ratio of $L$. denticornis on rye is higher - on average $72 \%$ and $83-93 \%$ on other crops. This agrees with our data for winter wheat where sex ratio of $L$. denticornis was $86.8 \%$ in 2002 and $82.6 \%$ in 2003. Sex ratio for H. aculeatus was $73.8 \%$ in 2002 and $62.5 \%$ in 2003 . The same sex ratio level (65.1-73.4\%) was found in winter rye (Šmatas, 2009). In our study, sex ratio of $F$. intonsa was $70.8 \%$ in 2002 and $50.9 \%$ in 2003 . Sex ratio of $F$. tenuicornis was $72.6 \%$ in 2002 , and $69.5 \%$ in 2003. Sex ratio of F. tenuicornis was much higher (78.3$97.8 \%$ ) in winter rye ( matas, 2009). In our trials males of A. obscurus, C. manicatus, F. palida and T. tabaci were not found at all, while females were found in both years. Sex ratio of other species found cannot be determined with certainty because of the sparsity of this species.

\section{Conclusions}

1. Among the 13 thrips species belonging to three thrips families in winter wheat there were 10 thrips species of Thripidae family, 2 species of Phlaeothripidae family and 1 species of Aeolothripidae family. Twelve species were phytophagous and one species (Aeolothrips intermedius) was zoophagous.

2. The predominant species in winter wheat were Limothrips denticornis (41.3\%), Haplothrips aculeatus (25.8\%) and Frankliniella tenuicornis (20.5\%).

3. Limothrips denticornis was the earliest thrips species found on winter wheat in spring in 2003 and the second earliest in spring 2002. 
4. An average sex ratio was: $84.7 \%$ of L. denticornis, $68.2 \%$ of $H$. aculeatus, $71.1 \%$ of $F$. Tenuicornis, and $60.9 \%$ of $F$. intonsa.

\section{Acknowledgements}

The paper presents research findings, obtained through the long-term research programme "Harmful organisms in agro and forest ecosystems (KOMAS)" implemented by Lithuanian Research Centre for Agriculture and Forestry.

Received 16032012 Accepted 08072013

\section{References}

Andjus L. 1998. Thrips species on wheat and barley in Yugoslavia: proceedings of the $6^{\text {th }}$ international symposium on Thysanoptera. Akdeniz University, Antalya, Turkey, p. 1-5

Buntin G. D., Beshear R. J. 1995. Seasonal abundance of thrips (Thysanoptera) on winter small grains in Georgia. Environmental Entomology, 24: 1216-1223

Gaafar N., El-Wakeil N., Volkmar Ch. 2011. Assessment of wheat ear insects in winter wheat varieties in central Germany. Journal of Pets Science. 84: 49-59 http://dx.doi.org/10.1007/s10340-010-0325-2

Kakol E., Kucharczyk H. 2004. The occurrence of thrips (Thysanoptera, Insecta) on winter and spring wheat in chosen regions of Poland. Acta Phytopathologica et Entomologica Hungarica. 39: 263-269 http://dx.doi.org/10.1556/APhyt.39.2004.1-3.25

Kobro S., Teksdal A. E., Andersen A. 2000. Cereals as host plants for thrips (Tysanoptera) in Norway. Norway Journal of Entomology, 47: 1-6

Köppä P. 1970. Studies on the thrips (Thysanoptera) species most commonly occurring on cereals in Finland. Annales Agriculturae Fenniae, 9: 191-265

Larsson H. 1988. Economic damage caused by cereal thrips in winter rye in Sweden. Acta Phytopathologica et Entomologica Hungarica, 23: 291-293

Larsson H. 2005. Economic damage by Limothrips denticornis in rye, triticale and winter barley. Journal of Applied Entomology, 129: 386-392 http://dx.doi.org/10.1111/j.1439-0418.2005.00986.x
Magurran A. E. 1988. Ecological diversity and its measurement. Princeton. USA. p. 192 http://dx.doi.org/10.1007/978-94-015-7358-0

Mound L. A. 1997. Biological diversity. Thrips as crop pests. Lewis T. (ed.). Harpenden, UK, p. 197-215

Schröder A. 2009. Evaluierung von Winterweizensorten zum Auftreten und Schadausmaß von Thysanopteren. Diplomarbeit Martin-Luther-Universität Halle-Wittenberg University, Germany, 94 p. (in German)

Sęczkowska K. 1970. Wstępne obserwacje nad biologią i występowaniem Limothrips denticornis Hal. (Thysanoptera). Annales universitatis Mariae CurieSkłodowska, C (25) : 303-312 (in Polish)

Szeflińska D. 2005. Density and the species structure of Thysanoptera (thrips) in winter rye and oat crops. Journal of Plant Protection Research, 45: 55-58

Šmatas R. 2007. Amarų ir tripsų plitimas ir žalos mažinimas javuose. Šiu dienu augalu apsauga mokslo ir agroverslo kontekste. Lithuanian Institute of Agriculture, p. 187-194 (in Lithuanian)

Šmatas R. 2009. Species structure and sex ratio of thrips (Tysanoptera) on winter rye (Secale cereale). ZemdirbysteAgriculture, 96 (4): 260-267

Šmatas R., Surkus J. 2005. Occurrence of thrips in winter cereals. Zemdirbyste-Agriculture, 91 (3): 95-106 (in Lithuanian)

Ullman D. E., Sherwood J. L., German T. L. 1997. Thrips as vectors of plant pathogens. Thrips as crop pests / Lewis T. (ed.). Harpenden, UK, p. 539-565

Varshney R. K., Balyan H. S., Langridge P. 2006. Wheat. Genome mapping and molecular breeding in plants. Cereals and millets. Kole Ch. (ed.). Berlin, Heidelberg, 1: 79-134

Vasiliu-Oromulu L. 2001. The dynamic of the sex ratio index of thrips populations in mountainous meadows. Thrips and Tospoviruses: proceedings of the $7^{\text {th }}$ international symposium on Thysanoptera. Calabria, Italy, p. 315-324

Wrensch D. L., Ebbert M. A. 1993. Evolution and diversity of sex ratio in insects and mites. London. UK. 652 p. http://dx.doi.org/10.1007/978-1-4684-1402-8

Zawirska I., Wałkowski W. 2000. Fauna and importance of thrips (Thysanoptera) for rye and winter wheat in Poland. Part I. Fauna of Thysanoptera on rye and winter wheat in Poland. Journal of Plant Protection Research, 40: 35-55

\title{
Tripsų (Thysanoptera) rūšių ịvairovė ir lyčių santykis Lietuvoje auginamuose žieminiuose kviečiuose
}

\author{
R. Šmatas, K. Tamošiūnas, V. Danytė \\ Lietuvos agrarinių ir miškų mokslų centro Žemdirbystès institutas
}

\section{Santrauka}

Tripsų rūšinès sudèties ir lyčių santykio žieminio kviečio (Triticum aestivum L.) pasèlyje tyrimai atlikti 20022003 m. Lietuvos žemdirbystès institute. Tripsu gausumo žieminiuose kviečiuose stebejimai pradèti javu krūmijimosi pradžioje (GS 21), baigti visiškos brandos tarpsniu (GS 89). Žieminiuose kviečiuose rasta 13 tripsų rūšių, kurios priklausė trims šeimoms: dešimties rūšiu tripsai priklausè Thripidae, dvieju - Phlaeothripidae ir vienos - Aeolothripidae šeimoms. Pagal mitybinę grupę iš rastų 13-os rūšių tripsų Aeolothrips intermedius priklausė zoofagams, likusios - fitofagams. Žieminių kviečių pasėlyje anksčiausiai pradejo plisti Frankliniella intonsa, F. tenuicornis, Haplothrips aculeatus ir Limothrips denticornis rūšiu tripsai. Sezono metu vyravo L. denticornis $(41,3 \%), H$. aculeatus $(25,8 \%)$ ir F. tenuicornis (20,5 \%) rūšių tripsai. L. denticornis rūšies tripsų lyčių santykis buvo $84,7 \%, H$. aculeatus $-68,2 \%, F$. tenuicornis $-71,1 \%, F$. intonsa $-60,9 \%$.

Reikšminiai žodžiai: Frankliniella tenuicornis, Haplothrips aculeatus, javiniai tripsai, Limothrips denticornis, Triticum aestivum. 